\title{
PENGARUH PENGGUNAAN APLIKASI YOUTUBE TERHADAP PERKEMBANGAN SOSIAL ANAK USIA 4-5 TAHUN
}

\author{
Maivy Hastuty ${ }^{1}$, Fahmi $^{2}$, Laily Rosidah ${ }^{3}$ \\ Fakultas Keguruan dan Ilmu Pendidikan, Universitas Sultan Ageng Tirtayasa \\ 22281470037untirta.ac.id ${ }^{1}$, fahmifahmi19@untirta.ac.id ${ }^{2}$, laily@untirta.ac.id ${ }^{3}$ \\ Hastuty, Maivy. Fahmi. Laily Rosidah. (2021). Pengaruh Penggunaan Aplikasi Youtube \\ Terhadap Perkembangan Sosial Anak. Jurnal Pelita PAUD, 6(1), 102-109 \\ doi: https://doi.org/10.33222/pelitapaud.v6i1.1511
}

Diterima:25-11-2021 Disetujui: 12-09-2021

Dipublikasikan:25-12-2021

Abstrak: Penggunaan aplikasi Youtube yang disajikan oleh kemajuan teknologi di era ini semakin meningkat. Bebasnya akses penggunaan aplikasi Youtube atau kurangnya pengetahuan orang tua dalam penggunaan aplikasi Youtube serta luputnya pengawasan orang tua, akan membuat video yang bisa terlihat oleh anak pun menjadi sangat beragam hingga pada akhirnya hal ini akan berdampak buruk bagi kesehatan anak dan perkembangan anak. Berdasarkan permasalahan tersebut, memberikan pemahaman kepada orang tua dan orang-orang terdekat di sekitar anak untuk memberikan pengawasan serta bimbingan sangatlah dibutuhkan sehingga perkembangan sosial anak dapat berkembang menjadi optimal. Penelitian ini bertujuan untuk mengetahui pengaruh penggunaan aplikasi Youtube terhadap perkembangan sosial anak. Penelitian ini menggunakan metode kuantitatif dengan jenis survei terhadap 100 orang pengasuh atau orang tua anak usia 4-5 tahun di Kecamatan Rajeg, Kabupaten TangerangBanten. Hasil penelitian ini menunjukkan bahwa nilai koefisien korelasi sebesar 0, 373 yang berada pada interval $0,20 \mathrm{~s} / \mathrm{d} 3,99$ sehingga memiliki tingkat pengaruh yang rendah. Dihasilkan juga persamaan linear $\mathrm{Y}=31.746+0,495$ yang berarti bahwa setiap $1 \%$ penambahan nilai penggunaan aplikasi Youtube, maka akan bertambah nilai perkembangan sosial anak usia 4-5 tahun sebesar 0,495. Dengan angka probabilitas $0,000<0,05$ maka dapat disimpulkan bahwa terdapat pengaruh yang signifikan atau searah antara penggunaan aplikasi Youtube terhadap perkembangan sosial anak.

Kata kunci: Youtube, Perkembangan Sosial, Anak Usia 4-5 Tahun

Abstract: The use of Youtube Application presented by technological advanced in this era is increasing. The free access to the use of the Youtube application or the lack of parental knowledge in the use of Youtube application and the absence of parental supervision, making videos that can be seen by children become very diverse so that in the end it will be have a negative impact on children's health and social development. Based on these problems, providing understanding to parents and the closest people around the child to provide supervision and guidance is needed so that the child's social development can develop optimally. This study aims to determine the effect of using Youtube application on children's social development. This study uses a quantitative method with a survey type of 100 caregivers or parents for children aged 4-5 years in Rajeg district, Tangerang Regency-Banten. The results of this study indicate that the value of the correlation coefficient is 0,373 which is in the interval 0,20 to 3,99 so it has a low level of influence. It also producesa linear equation $Y=31.746+0,495$ which means that for every $1 \%$ increase in the value of using Youtube application for social development of children aged 4-5 years old will increase by 0,495. With a probality number of 0,000 $<0,05$ it can be concluded that there is a significant or unidirectional influence between the use of the Youtube application on children's social development.

Keywords: Youtube, Social Development, Children Aged 4-5 Years

http://jurnal.upmk.ac.id/index.php/pelitapaud 


\section{PENDAHULUAN}

Perkembangan sosial anak merupakan tingkat keterampilan jalinan interaksi anak dengan orangorang disekitarnya untuk berperilaku sesuai dengan norma atau aturan dalam lingkungan masyarakat secara luas yang diperoleh dari pengalamannya melalui kegiatan interaksinya atau kemampuan belajarnya dengan orang tua, guru, dan teman bermainnya.

Menurut Setiyaningrum (2017:25) perkembangan sosial anak adalah suatu proses dalam kehidupan anak untuk berperilaku sesuai dengan norma atau aturan dalam lingkungan kehidupan anak. Sehingga Perkembangan anak usia dini dapat diperoleh dari lingkungan sekitarnya, dimana lingkungan sekitar anak menjadi hal yang penting terhadap perkembangan anak. Pada usia 4-5 tahun, anak sudah mulai tertarik untuk berhubungan dengan orang-orang di luar lingkungannya. Di usia ini anak berada dalam awal masa kanak-kanak yang sering disebut sebagai masa perkelompok, sehingga di masa ini anak senang berkelompok dengan anakanak sebayanya untuk bisa bermain bersama atau mengobrol serta menceritakan berbagai hal yang diketahuinya. Danescu Niculescu Mizil, Lee, Pang, \& Kleinberg (2011) menyatakan bahwa terdapat 3 jenis interaksi sosial (sosialisasi) yaitu hubungan antara individu satu dengan individu lain; hubungan individu dengan kelompok; atau hubungan kelompok dengan kelompok (Setiadi, 2020, p. 27). Namun setahun belakangan ini dunia dikejutkan dengan pandemi COVID-19, dimana dengan adanya peristiwa tersebut membuat setiap orang diharuskan untuk menjaga jarak dengan orang lain dan sangat dianjurkan untuk tidak keluar rumah jika tidak ada kepentingan. Hal ini pun membuat anakanak pun merasakan dampaknya, dimana anak jadi tidak bisa bersosialisasi dengan teman-teman sebayanya. Salah satu kebijakan yang diberikan pemerintah dalam mencegah terjadinya penularan virus COVID-19 adalah dengan dilakukannya pembelajaran di rumah atau dengan melakukan berbagai kegiatan di dalam rumah. Kemudian diketahui pula bahwa dunia telah berada pada era revolusi 4.0 dan sedang memasuki era 5.0, tak terkecuali di Indonesia. Sehingga pada era ini, penggunaan teknologi menjadi hal yang tidak dapat dipisahkan. Ayu and Triana (2021) menyatakan bahwa dalam era ini akan membiasakan manusia terhadap penggunaan teknologi informasi untuk pemenuhan kebutuhan dan peningkatan kompetensi manusia itu sendiri. Berada dalam era sekarang ini dengan terjadinya peristiwa pandemi COVID-19 membuat penggunaan media sosial yang merupakan salah satu teknologi digital menjadi lebih meningkat. Menurut Lidwina (2021) akses penggunaan Youtube di Indonesia pada tahun 2021 sebanyak 93\%. Kebijakan untuk tetap berada di dalam rumah karena menghindari penularan virus COVID-19 membuat beberapa orang merasa jenuh dan tak terkecuali anak-anak usia dini. Dengan begitu penggunaan media sosial menjadi salah satu cara untuk mengatasi kejenuhan yang dirasakan. Penggunaan media sosial yang meningkat dan dengan mudahnya mendapatkan berbagai informasi serta membuat anak usia dini sulit dalam membedakan mana informasi yang benar serta bermanfaat. Pesatnya perkembangan teknologi informasi dan komunikasi yang semakin beragam baik dari segi bentuk hingga berbagai fungsinya seperti Smartphone menjadi lebih menarik perhatian anak. Beragamnya fitur dan fungsi yang ditawarkan menjadi kebutuhan sehari-hari yang tidak terlepaskan karena kemudahan dalam pemakaiannya, sehingga membuat anak menjadi lebih mudah akrab dengan Smartphone. Salah satu fitur yang menarik perhatian anak di Smartphone adalah aplikasi Youtube. Menurut Salehudin (2020) alasan utama aplikasi Youtube dipakai oleh anakanak adalah karena Aplikasi Youtube mengandung konten video, audio visual yang menarik, dan memiliki semua kesukaan anak. Youtube merupakan aplikasi yang menyediakan berbagai konten video di dalamnya seperti berita, edukasi (pendidikan), hiburan, komedi dan yang sekarang sedang naik daun yaitu Vlog (Janah et al., 2019, p. 111). Aplikasi Youtube adalah software atau alat terapan yang menyediakan berbagai konten video (berita, edukasi (pendidikan), hiburan, komedi, dan lain sebagainya) dan merupakan salah satu rancangan sistem pelayanan dari Google dalam memfasilitasi penggunanya untuk meng-upload video dan bisa diakses oleh pengguna yang lain dimana pun dan kapan pun secara gratis. Menurut Rohmatulloh dkk (2020) yang menyatakan bahwa Youtube biasanya digunakan untuk melihat konten mulai dari vlog, prank, game, musik, teen live, parodi, vine, review, rekomendasi, fakta unik, film, eksperimen, dubbing, masakan, menggambar, how to, family, kartun.

Bebasnya akses penggunaan aplikasi Youtube atau kurangnya pengetahuan orang tua dalam penggunaan aplikasi Youtube serta luputnya pengawasan orang tua, membuat video yang bisa terlihat oleh anak pun menjadi sangat beragam. Konten video di aplikasi Youtube bisa berupa konten positif (edukasi) dan konten negatif (pornografi, horor dan kekerasan). Berdasarkan 
permasalahan tersebut, memberikan pemahaman kepada orang tua dan orang-orang terdekat di sekitar anak untuk memberikan pengawasan serta bimbingan sangatlah dibutuhkan. Sebenarnya anak usia dini diperbolehkan untuk menggunakan aplikasi Youtube, tetapi harus dengan durasi waktu yang ditentukan atau dengan pendampingan dari orang tua. Karena anak masih kurang pertimbangan dalam memutuskan sesuatu, maka adanya orang tua adalah untuk memberikan pemahaman dari konten video yang ditonton anak dalam aplikasi Youtube. Jika hal tersebut diabaikan maka perkembangan anak akan terganggu, oleh karena itu penelitian ini dilakukan untuk melihat pengaruh penggunaan aplikasi Youtube terhadap perkembangan sosial anak usia 4-5 tahun.

\section{METODE PENELITIAN Jenis Penelitian}

Pada penelitian ini, metode penelitia yang digunakan adalah metode penelitian kuantitatif dengan jenis survei. Penelitian kuantitatif dengan metode survei merupakan penelitian survei dalam kategori survei analitis (analytical survey), dimana menurut Morissan (2017:166) bahwa hasil survei memungkinkan peneliti untuk menguji hubungan diantara variabel dan menarik kesimpulan dari hubungan tersebut. Dengan menggunakan teknik pengambilan sampel secara random, pengumpulan data menggunakan instrumen penelitian, dan teknik analisis data yang bersifat statistik.

\section{Waktu dan Tempat Penelitian}

Penelitian ini dilaksanakan di Kecamatan Rajeg, Kabupaten Tangerang-Banten.

\section{Subjek Penelitian}

Subjek penelitian ini adalah pengasuh atau orang tua anak usia 4-5 tahun yang menggunakan aplikasi Youtube. Populasi anak usia 4-5 tahun di Kecamatan Rajeg, Kabupaten Tangerang-Banten adalah 18.477 anak yang tersebar di 13 desa (Koordinator Statistik Kecamatan Rajeg, 2018, p. 35). Dengan teknik pengambilan sampel secara simple random sampling, peneliti menggunkan rumus Slovin yaitu sebagai berikut: maka dapat diketahui bahwa sampel yang digunakan dalam penlitian ini sebanyak 100 .

\section{Prosedur}

Prosedur penelitian merupakan langkah-langkah atau tahapan dalam pelaksanaan penelitian. Prosedur pelaksanaan dalam penelitian ini didasarkan pada (Hardiningrum, 2017, p. 14) dengan langkah berikut:

Tahap pra penelitian, dimana dalam tahap ini peneliti akan menentukan sampel dan instrumen penelitian yang terdiri dari item-item. Item-item tersebut kemudian di uji validitas dan reliabilitas serta setelah dinyatakan valid dan reliabel maka akan digunakan sebagai instrument penelitian untuk menilai perkembangan sosial anak dan penggunaan aplikasi Youtube oleh anak.

Tahap pelaksanaan penelitian, dimana peneliti akan menyebarkan instrument penelitian yang berupa kuesioner berbentuk Google Form kepada 100 orang pengasuh atau orang tua anak usia 4-5 tahun di Kecamatan Rajeg yang menggunakan aplikasi Youtube.

Tahap analisis data, dimana Setelah didapatkan data yang diperlukan kemudian dilakukan pengolahan data dan analisis data yang di uji normalitas, uji korelasi, uji regresi linear, uji determinasi (R-Square) dan uji parsial (Uji t) menggunakan program komputer SPSS Statistic 25.

Tahap penulisan laporan, dimana setelah didapatkan hasil dari oleh data penelitian kemudian menyusun laporan dan mempublikasikan hasil penelitian ke dalam jurnal agar dapat bermanfaat luas.

Data Instrumen dan Teknik Pengumpulan Data

Dalam menilai variabel-variabel yang akan diteliti, maka instrumen penelitian menjadi hal yang sangat dibutuhkan. Instrumen penelitian dalam penelitian ini terdiri dari 10 item pernyataan tentang penggunaan aplikasi Youtube yaitu sebagai berikut: 
Tabel 1. Instrumen Penggunaan Aplikasi Youtube

\begin{tabular}{|c|c|c|}
\hline No. & Indikator & Sub indikator \\
\hline 1 & $\begin{array}{l}\text { Penggunaan } \\
\text { Aplikasi } \\
\text { Youtube }\end{array}$ & $\begin{array}{l}\text { Anak mampu membuka } \\
\text { aplikasi Youtube tanpa } \\
\text { bantuan orang lain }\end{array}$ \\
\hline 2 & & $\begin{array}{lrr}\text { Anak mampu membuka } & \text { aplikasi } \\
\text { video dalam } & \text { aldiri }\end{array}$ \\
\hline 3 & $\begin{array}{l}\text { Lama } \\
\text { Penggunaan } \\
\text { Aplikasi }\end{array}$ & $\begin{array}{l}\text { Anak menonton video dalam } \\
\text { aplikasi Youtube lebih dari } \\
120 \text { menit per hari }\end{array}$ \\
\hline 4 & Youtube & $\begin{array}{l}\text { Anak menonton video dalam } \\
\text { aplikasi Youtube lebih dari } \\
\text { 30-60 menit per hari }\end{array}$ \\
\hline 5 & & $\begin{array}{l}\text { Anak tidak pernah menonton } \\
\text { video dalam aplikasi } \\
\text { Youtube dalam sehari }\end{array}$ \\
\hline 6 & $\begin{array}{l}\text { Konten } \\
\text { Video }\end{array}$ & $\begin{array}{l}\text { Anak mampu memilih } \\
\text { konten video sendiri }\end{array}$ \\
\hline 7 & $\begin{array}{l}\text { dalam } \\
\text { Aplikasi }\end{array}$ & $\begin{array}{l}\text { Anak tertarik dengan } \\
\text { berbagai konten video }\end{array}$ \\
\hline 8 & Youtube & $\begin{array}{l}\text { Anak fokus (tidak mudah } \\
\text { teralihkan konsentrasinya) } \\
\text { ketika sedang menonton }\end{array}$ \\
\hline 9 & $\begin{array}{l}\text { Motivasi } \\
\text { Anak dalam } \\
\text { Penggunaan } \\
\text { Aplikasi }\end{array}$ & $\begin{array}{l}\text { Anak memiliki rasa ingin } \\
\text { tahu yang tinggi ketika } \\
\text { menggunakan } \\
\text { Youtube }\end{array}$ \\
\hline 10 & Youtube & $\begin{array}{l}\text { Anak senang } \\
\text { menggunakan } \\
\text { Youtube }\end{array}$ \\
\hline
\end{tabular}

Sumber: Olahan Penulis (2021)

Sedangkan untuk instrumen perkembangan sosial anak usia 4-5 tahun terdiri dari 15 item. Instrumen penelitian kemudian di uji validitas untuk mengetahui kualitas instrument terhadap suatu objek yang akan diteliti lebih lanjut dan uji reliabilitas untuk mengetahui konsistensi dari instrument sebagai alat ukur sehingga hasil ukur dapat dipercaya (Muamanah, 2018, p. 72).

Berdasar hasil uji validitas diketahui bahwa item pernyataan untuk variabel perkembangan sosial yang valid berjumlah 14 dari 15 pernyataan karena 1 pernyataan dinyatakan tidak valid. Hal ini dikarenakan $\mathrm{r}_{\text {hitung }} \leq \mathrm{r}_{\text {tabel }}$ pada taraf signifikasi 0,05 (5\%) dengan $\mathrm{N}=100$ dalam $\mathrm{df}=98$ yaitu $0,196$.
Tabel 2. Instrumen Perkembangan Sosial Anak Usia 4-5 Tahun

\begin{tabular}{|c|c|c|}
\hline No. & Indikator & Sub indikator \\
\hline & Kemampuan & Anak mampu memenuhi \\
\hline & \multirow[t]{4}{*}{ Mandiri } & $\begin{array}{l}\text { kebutuhan/keinginannya } \\
\text { sendiri }\end{array}$ \\
\hline & & $\begin{array}{l}\text { Anak mampu menerima tugas } \\
\text { yang diberikan }\end{array}$ \\
\hline & & $\begin{array}{l}\text { Anak mampu menunjukkan } \\
\text { sikap mandiri dalam }\end{array}$ \\
\hline & & $\begin{array}{l}\text { menyelesaikan tugasnya tanpa } \\
\text { bantuan }\end{array}$ \\
\hline & Kemampuan & Anak mampu membantu orang \\
\hline & \multirow[t]{5}{*}{ Bersosialisasi } & lain \\
\hline & & Anak mampu mengajak orang \\
\hline & & lain berkomunikasi \\
\hline & & $\begin{array}{l}\text { Anak mampu merespon } \\
\text { perilaku orang lain dengan } \\
\text { wajar }\end{array}$ \\
\hline & & $\begin{array}{l}\text { Anak mampu berbagi dengan } \\
\text { orang lain }\end{array}$ \\
\hline & \multirow{11}{*}{$\begin{array}{l}\text { Kemampuan } \\
\text { Berinteraksi } \\
\text { dengan } \\
\text { Lingkungan }\end{array}$} & Anak mampu menunjukkan \\
\hline & & $\begin{array}{l}\text { sikap antusiasme dalam } \\
\text { melakukan kegiatan }\end{array}$ \\
\hline & & $\begin{array}{l}\text { Anak mampu menunjukkan } \\
\text { perilaku kooperatif dengan } \\
\text { orang lain }\end{array}$ \\
\hline & & $\begin{array}{l}\text { Anak mampu menyesuaikan } \\
\text { diri dengan orang lain dan } \\
\text { lingkungan sekitarnya }\end{array}$ \\
\hline & & $\begin{array}{l}\text { Anak mampu berinteraksi } \\
\text { dengan orang lain }\end{array}$ \\
\hline & & $\begin{array}{l}\text { Anak mampu menunjukkan } \\
\text { perilaku taat terhadap aturan } \\
\text { sehari-hari dalam lingkungan } \\
\text { sekitarnya }\end{array}$ \\
\hline & & $\begin{array}{l}\text { Anak mampu menyampaikan } \\
\text { pendapatnya kepada orang lain }\end{array}$ \\
\hline & & $\begin{array}{l}\text { Anak mampu mendengarkan } \\
\text { dan menghargai orang lain saat } \\
\text { berbicara }\end{array}$ \\
\hline & & Anak mampu ikut serta dalam \\
\hline & & kegiatan di sekitar \\
\hline & & lingkungannya \\
\hline
\end{tabular}

Sumber: Suminah et al. (2015:15-21)

Setelah melakukan uji validitas, selanjutnya dilakukan uji reliabilitas untuk setiap variabel penelitian. Uji reliabilitas dilakukan setelah semua pertanyaan dinyatakan valid (M. A. A. Gunawan \& Zubaidah, 2017, pp. 38-39). Hasil uji reliabilitas untuk variabel perkembangan sosial adalah 0,919 dan hasil dari uji reliabilitas untuk variabel penggunaan aplikasi Youtube adalah 0,815. Karena nilai Cronbach's Alpha lebih besar dari 0, 05 maka dapat disimpulkan bahwa instrumen penelitian ini bersifat reliabel. 
Setelah instrumen penelitian dinyatakan valid dan reliabel, selanjutnya teknik pengumpulan data dalam penelitian ini menggunakan kuesioner atau angket dan dokumentasi. Kuesioner atau yang disebut angket merupakan suatu teknik pengumpulan data pada penelitian dengan cara memberikan seperangkat pertanyaan atau pernyataan tertulis kepada responden untuk kemudian dijawab (Munasiatul, 2020, p. 26). Kuesioner berbentuk Google Form disebarkan kepada orang tua atau pengasuh anak usia 4-5 tahun di kecamatan Rajeg Kabupaten Tangerang-Banten. Berikut adalah tahapan pelaksaannya:

Google Form berbentuk link disebarkan melalui aplikasi WhatsApp. Orang tua atau pengasuh anak usia 4-5 tahun bisa menekan tautan link yang sudah dikirimkan dan mengisi kuesionernya sesuai dengan keadaan yang sebenarnya. Peneliti dengan otomatis akan menerima data yang telah diisi oleh orang tua atau pengasuh anak usia 4-5 tahun. Sedangkan dokumentasi dalam penelitian ini berupa foto-foto kegiatan pada saat melaksanakan penelitian.

\section{Teknik Analisis Data}

Teknik analisis data dalam penelitian ini menggunakan analisis statistik paramentris, dimana analisis data dilakukan untuk menguji parameter populasi melalui statistik atau menguji ukuran populasi melalui data sampel. Menurut Branch dalam Zaningsih (2018:57) analisis data merupakan cara yang paling menentukan untuk menyusun dan mengolah data yang terkumpul dalam penelitian agar dapat dipertanggungjawabkan.

Uji yang digunakan dalam menganalisis data penelitian adalah uji normalitas untuk mengetahui apakah data yang diperoleh dalam sebuah penelitian berdistribusi normal, uji korelasi untuk menentukan hubungan antar variabel dalam suatu penelitian, uji regresi linear sederhana untuk menunjukkan arah hubungan dengan mengukur kekuatan antar variabel dalam penelitian, uji determinasi (RSquare) untuk mengukur seberapa jauh kemampuan model dalam variasi variabel dependen (Wijayanti, 2016, p. 76), dan uji parsial (uji t) yang digunakan untuk membandingkan nilai rata-rata sampel yang diamati dengan nila rata-rata yang diharapkan secara normal dari distribusi nilai rata-rata (Morissan, 2017, p. 330).

\section{HASIL DAN PEMBAHASAN}

Hasil penelitian didapatkan setelah melalui pengolahan data dan analisis data menggunakan uji normalitas, uji korelasi, uji regresi linear sederhana, uji determinasi ( $\mathrm{R}$ Square) dan uji parsial (uji t). berikut adalah hasil yang telah didapatkan:

\section{Uji Normalitas}

Uji normalitas data dimaksudkan untuk memperlihatkan bahwa data sampel berasal dari populasi yang berdistribusi normal (M. A. Gunawan, 2015, p. 65). Dalam penelitian ini uji normalitas data menggunakan analisis statistik yaitu One-Sample Kolmogorov-Sminornov (KS). Kriteria dalam menentukan apakah data berdistribusi normal adalah dengan cara membandingkan nilai Sig. (2-tailed) pada tabel Kolmogorov-Sminornov (K-S) dengan taraf signifikan 0,05 (5\%). Dengan demikian, dasar pengambilan keputusan bahwa jika $p$ dari koefisien K-S > 0,05, maka data berdistribusi normal. Sebaliknya jika $p$ dari kofisien K-S < 0,05, maka data tidak berdistribusi normal (Mawaddah, 2018, p. 43).

Berdasarkan hasil uji normalitas yang telah dilakukan oleh peneliti menggunakan program komputer SPSS Statistic 25 diketahui bahwa nilai Sig. (2-tailed) adalah 0,200 >0,05. Maka dapat disimpulkan bahwa nilai residual dalam penelitian ini berdistribusi normal, sehingga ini membuktikan bahwa data sampel dari populasi yang diteliti bersifat normal.

\section{Uji Korelasi}

Analisis data menggunakan uji korelasi dilakukan untuk menentukan kekuatan hubungan antara variabel dependen yaitu perkembangan sosial dengan variabel independen yaitu penggunaan aplikasi Youtube. Riyanto and Hatmawan (2020:131) menyatakan bahwa analisis korelasi tidak membedakan antara variabel dependen (variable terikat) dengan variabel independen (variable bebas). Sehingga analisis korelasi juga dapat menentukan kekuatan hubungan diantara variabel dalam penelitian.

Dalam penelitian ini, uji korelasi produk momen yang digunakan, untuk menguji hipotesis hubungan antara satu variabel independen (Perkembangan sosial) dan variabel dependen (Penggunaan Aplikasi Youtube) (Sugiyono, 2013, p. 153). Hasil dari analisis data dengan uji korelasi product moment diketahui bahwa nilai Pearson Correlation sebesar 0,373.

Tabel 3. Kategori Tingkat Hubungan

\begin{tabular}{ccc}
\hline No & Interval Koefisien & Tingkat Hubungan \\
\hline 1. & $0,00-0,199$ & Sangat Rendah \\
2. & $0,20-0,399$ & Rendah \\
3. & $0,40-0,599$ & Sedang \\
4. & $0,60-0,799$ & Kuat \\
\hline
\end{tabular}




5. $0,80-1,000 \quad$ Sangat Kuat

Sumber: (Muamanah, 2018, p. 73)

Berdasarkan tabel 3 dapat disimpulkan bahwa penelitian ini memiliki tingkat pengaruh antar variabel rendah karena berada pada interval kategori $0,20 \mathrm{~s} / \mathrm{d}$ 0,399. Dengan diketahui nilai Sig. (2tailed) sebesar 0,000. Maka dapat diketahui bahwa hal ini menjelaskan bahwa angka probabilitas yang sebesar $0,000<0,05$ sehingga dapat disimpulkan bahwa pengaruh antar variabel dalam penelitian ini signifikan atau searah.

Anak yang berinteraksi dengan berbagai konten video di Youtube seperti video tentang tokoh kartun kesukaannya, membuat anak secara tidak langsung akan terstimulasi berupa audio dan visual sehingga anak menjadi sangat terhibur dan tertarik untuk menonton berbagai video lainnya. Tokoh kesukaannya yang menjadi peran di dalam video yang ditontonnya membuatnya ingin terus menonton lagi dan lagi. Hal tersebut juga akan membuat anak ketergantungan dan mengabaikan aktifitas lainnya seperti malas bergerak serta berinteraksi dengan orang-orang disekitarnya. Hurlock menyatakan bahwa anak yang lebih menyukai interaksi dengan manusia daripada benda akan lebih mengembangkan kecakapan sosial sehingga mereka lebih populer daripada anak yang interaksi sosialnya terbatas (Hurlock, 1978, p. 117). Dengan melakukan uji korelasi dalam penelitian ini, maka dapat diketahui bahwa terdapat hubungan atau pengaruh dari penggunaan aplikasi Youtube dengan perkembangan sosial anak usia 4-5 tahun.

\section{Uji Regresi Linear Sederhana}

Pada penelitian ini uji regresi linear sederhana merupakan uji yang dilakukan untuk menganalisis kekuatan hubungan penggunaan aplikasi Youtube terhadap perkembangan sosial anak. Berdasarkan data yang telah diperoleh dalam kuesioner yang telah dibagikan, analisis data dilakukan menggunakan bantuan dari program SPSS versi 25 . diketahui hasil yang diperoleh melalui nilai Constant (a) sebesar 31.746, sedangkan untuk nilai penggunaan aplikasi Youtube (b/koefisien regresi) sebesar 0,495. Dengan persamaan regresi $\mathrm{Y}=$ $31.746+0,495 \mathrm{x}$ maka dapat diartikan nilai Constant (a) yang sebesar 31.746 dengan koefisien regresi bernilai 0,495 menjelaskan bahwa setiap penambahan $1 \%$ nilai penggunaan aplikasi Youtube maka nilai perkembangan sosial anak akan bertambah 0.495. Sehingga koefisien tersebut bersifat positif dan dapat disimpulkan bahwa arah pengaruh penggunaan aplikasi Youtube terhadap perkembangan sosial anak adalah positif. Dengan menjadikan aplikasi Youtube sebagai media untuk belajar dan mencari informasi serta hiburan, maka perkembangan sosial anak akan berkembang ke arah yang positif dan dapat dikatakan baik (Putra \& Patmaningrum, 2018).

\section{Uji Determinasi (R Square)}

Uji determinasi dalam penelitian ini bertujuan untuk mengetahui seberapa besar pengaruh variabel X (Penggunaan Aplikasi Youtube) terhadap variabel Y (Perkembangan Sosial Anak). Dengan dilakukannya perhitungan statistik, data yang telah dianalisis dapat disimpulkan menggunakan koefisiensi determinasi $\left(\mathrm{R}^{2}\right)$.

Hasil dari analasis tersebut dapat diketahui bahwa nilai hubungan $(\mathrm{R})$ adalah 0,373 sehingga dari hasil nilai tersebut maka akan didapatkan nilai dari koefisien determinasi ( $\mathrm{R}$ Square) sebesar 0,139. Hal ini menunjukkan bahwa variabel terikat Perkembangan Sosial anak akan mempengaruhi variabel bebas penggunaan aplikasi Youtube sebesar 13,9\%. Sedangkan untuk $86,1 \%$ dari variabel perkembangan sosial anak dapat dipengaruhi oleh variabel lain di luar model yang diteliti dalam penelitian ini.

Dengan diketahui bahwa penggunaan aplikasi Youtube mempengaruhi perkembangan sosial anak usia 4-5 tahun sebesar 13,9\% dan 86,1\% dari variabel lain seperti faktor internal (genetika; perbedaan ras, etnis, bangsa dan agama; umur;jenis kelamin; serta keadaan fisik dan faktor keturunan), dan faktor eksternal (lingkungan sosial, kematangan intelektual, psikologis, lingkungan biologis, psikososial) (Putri, 2019, p. 18). Perkembangan sosial individu ditandai dengan pencapaian kematangan dalam interaksi sosialnya, bagaimana ia mampu bergaul, beradaptasi dengan lingkungannya dan menyesuaikan diri terhadap norma-norma kelompok (Solicha \& Na'imah, 2020, p. 202). Dengan adanya interaksi diantara anak dengan orang-orang disekitarnya, maka akan membuatnya memiliki kepribadian sosial. Kepribadian sosial menjadi hal yang harus dimiliki oleh anak sejak usia dini, sehingga saat anak tubuh menjadi dewasa tidak akan mengalami kesulitan dalam bersosialisasi dengan lingkungan masyarakat umum.

Uji Parsial (Uji t)

Dalam penelitian ini, Dasar pengambilan keputusan adalah dengan membandingkan nilai Sig. (2-talled) dengan nilai $\alpha=0,05(5 \%)$. Dapat diketahui bahwa nilai signifikansi adalah sebesar $0,000<0,05$. Sehingga dapat disimpulkan bahwa variabel penggunaan aplikasi Youtube 
(X) berpengaruh terhadap variabel perkembangan sosial anak (Y). Sedangkan berdasarkan nilai $t$ dalam penelitian ini diketahui bahwa nilai $t_{\text {tabel }}$ adalah 0,196 dan berdasarkan tabel 7 dapat diketahui bahwa nilai thitung sebesar 3.974, sehingga menghasilkan $t_{\text {hitung }}>t_{\text {tabel }}$ maka hipotesis diterima. Dimana dalam hal ini nilai $t_{\text {hitung }}$ sebesar $3.974>0,196$ nilai $t_{\text {tabel. }}$. Maka dapat disimpulkan bahwa variabel penggunaan aplikasi Youtube (X) berpengaruh terhadap variabel perkembangan sosial anak (Y). Hal ini membuktikan bahwa dengan menonton video dalam aplikasi Youtube seperti menonton video (film) tokoh kartun atau animasi kesukaan anak, tanpa sadar membuat anak menjadi mencontoh sikap atau perilaku dari apa yang telah ditontonnya dalam video tersebut. Sayekti (2019:165) menyatakan Film merupakan media yang efektif untuk dipergunakan dalam menyampaikan pendidikan kepada anak (Ratna \& Hutasuhut, 2020, p. 1240). Dengan menggunakan aplikasi Youtube untuk menonton video yang bersifat edukatif akan mengajarkan atau mencontohkan kepada anak tentang cara dalam bersikap. Hal ini yang kemudian akan mempengaruhi perkembangan sosial anak karena seorang anak tidak dapat belajar hidup bermasyarakat dengan orang lain jika sebagian besar waktunya hanya dipergunakan untuk kepentingan dirinya sendiri (Ckurnia et al., 2017, p. 64). Sehingga orang tua atau pengasuh diharapkan untuk lebih memperhatikan kegiatan anak.

\section{SIMPULAN}

Berdasarkan pengolahan data terhadap 100 responden yang telah dilakukan, hasil pengujian variabel penggunaan aplikasi Youtube terhadap perkembangan anak dengan menggunakan uji determinasi dapat diketahui nilai adjusted $R$ Square sebesar 0,130. Hal ini menjelaskan bahwa pengaruh dari variabel terikat perkembangan sosial anak dapat dijelaskan oleh variabel bebas penggunaan aplikasi Youtube, yaitu sebesar 13\%. Dapat diketahui juga bahwa hasil dari uji-t yang telah dilakukan menunjukkan variabel penggunaan aplikasi Youtube mempunyai arah koefisien positif sebesar 0,495 dengan signifikansi sebesar 0,000 $<0,05$ serta nilai $t_{\text {hitung }}$ sebesar 3.974 dan nilai $\mathrm{t}_{\text {tabel }}$ sebesar 0,196 yang berarti $\mathrm{t}_{\text {hitung }}>\mathrm{t}_{\text {tabel }}$. Hal tersebut menunjukkan bahwa variabel penggunaaan aplikasi Youtube berpengaruh terhadap perkembangan sosial anak.

\section{DAFTAR PUSTAKA}

Ayu, I. G., \& Triana, I. (2021). Pengenalan Literasi Digital melalui Cerita Narasi Berbahasa Inggris pada Aplikasi Youtube sebagai Penanaman Karakter Anak. Kajian Pendidikan FKIP, 12(1), $128-139$.

Ckurnia, N., Haerudin, D., \& Solihati, A. (2017). Meningkatkan Keterampilan Sosial Anak Usia Dini Melalui Metode Bermain Peran. Pelita PAUD, 2(1), 63-76.

Gunawan, M. A. (2015). Statistik Penelitian Bidang Pendidikan, Psikologi, dan Sosial (1st ed.). Parama Publishing.

Gunawan, M. A. A., \& Zubaidah, Z. (2017). Hubungan Durasi Penggunaan Gadget Terhadap Perkembangan Sosial Anak Prasekolah di TK PGRI 33 Sumurboto, Banyumanik. Universitas Diponegoro.

Hardiningrum, A. \& F. (2017). Peran Orangtua Dalam Menstimulasi Perkembangan Sosial Anak. 1(2), 110.

Hurlock, E. B. (1978). Bab Lima Masa Awal Kanakkanak.pdf. In Child Development (6th ed., pp. 108144). Mc Graw Hill, Inc.

Janah, M. M., Fadhli, M., \& Kristiana, D. (2019). Hubungan Intensitas Menonton Youtube dengan Perkembangan Sosial emosional Anak Usia 5-6 Tahun. Jurnal Ilmiah Mahasiswa Universitas Muhammadiyah Ponorogo, 3(2), 110-116.

Koordinator Statistik Kecamatan Rajeg. (2018). Kecamatan Rajeg Dalam Angka 2019 (Seksi Integrasi Pengolahan dan Diseminasi Statistik (ed.)). BPS Kabupaten Tangerang.

Lidwina, A. (2021). 94 \% Orang Indonesia Akses Youtube dalam Satu Bulan Terakhir. 17 Februari . 16.00

WIB.

https://databoks.katadata.co.id/datapublish/2021/0 2/17/94-orang-indonesia-akses-youtube-dalamsatu-bulan-

terakhir\#: :text=sebanyak\%252094\%2525\%2520 pengguna $\% 2520$ internet $\% 2520$ berusia,paling $\% 25$ $20 \% 25$ tinggi\%2520dibandingkan\%2520platform $\% 25201$ lainnya

Mawaddah, I. (2018). Pengaruh Intensitas Menonton Tayangan Gaming pada Akun Youtube Reza Oktovian Terhadap Perilaku Imitasi Bahasa Anak. UIN Syarif Hidayatullah Jakarta.

Morissan. (2017). Metode Penelitian Survei (5th ed.). PT Fajar Interpratama Mandiri.

Muamanah, S. (2018). Pengaruh Pola Asuh Orang Tua Terhadap Perkembangan Sosial Emosional Anak Usia 4-5 Tahun di Desa Bandar Abung Kecamatan Abung Surakarta Kabupaten Lampung Utara Skripsi [UNIVERSITAS ISLAM NEGERIRADEN INTAN LAMPUNG]. http://repository.radenintan.ac.id/5525/1/Skripsi Full.pdf

Munasiatul, I. (2020). Pengaruh Penggunaan Media Sosial Youtube terhadap Perilaku Positif Siswa 
Kelas 5 di MI Nurul Iman Kebonsari Madiun (Vol. 21, Issue 1). Institut Agama Islam Negeri Ponorogo.

Putra, A., \& Patmaningrum, D. A. (2018). Pengaruh Youtube di Smartphone Terhadap Perkembangan Kemampuan Komunikasi Interpersonal Anak. Jurnal Penelitian Komunikasi, 21(2), 159-172. https://doi.org/10.20422/jpk.v21i2.589

Putri, D. A. (2019). Pengaruh Lama Penggunaan Gadget Terhadap Pencapaian Perkembangan Sosial Anak Prasekolah di TK dan PAUD Jogodayuh Kecamatan Geger Kabupaten Madiun. STIKES Bhakti Husada Mulia Madiun.

Ratna, A., \& Hutasuhut, S. (2020). Analisis Pengaruh Film Nussa dan Rara terhadap Empati Anak Usia Dini di Kota Padang. Jurnall Pendidikan Tambusai, 4(2), 1237-1246.

Riyanto, S., \& Hatmawan, A. A. (2020). Metode Riset Penelitian Kuantitatif Penelitian Di Bidang Manajemen, Teknik ... - Slamet Riyanto, Aglis Andhita Hatmawan - Google Buku. In 1 Januari (1st ed.). DEEPUBLISH. https://books.google.co.id/books?hl=id\&lr=\&id= W2vXDwAAQBAJ\&oi=fnd\&pg=PP1\&dq=info:s eJVt4qXp64J:scholar.google.com/\&ots=Zgqf4PIb CV\&sig=afBrdQ7oB3trK65irYZ1NiwK3XY\&re dir_esc $=\mathrm{y} \# \mathrm{v}=$ onepage $\& \mathrm{q} \& \mathrm{f}=$ true

Setiadi, E. M. (2020). Pengantar Ringkas Sosiologi:Pemahaman Fakta dan Gejala Permasalahan sosial (Teori, Aplikasi, dan Pemecahannya) (1st ed.). Kencana.

Setiyaningrum, E. (2017). Buku Ajar Tumbuh Kembang Anak Usia 0-12 Tahun. In Proceedings of the 20th USENIX Security Symposium.

Solicha, I., \& Na'imah. (2020). Faktor yang Mempengaruhi Perkembangan Anak Usia Dini. Pelita PAUD, 4(2), 197-207.

Sugiyono. (2013). Metode Penelitian Kuantitatif, Kualitatif, dan $R \& D$ (19th ed.). ALFABETA, CV.

Suminah, E., Nugraha, A., Yusuf, F., \& Puspita, W. A. (2015). Kerangka Dasar dan Struktur Kurikulum 2013 Pendidikan Anak Usia Dini (E. Yulaelawati \& K. Restuningsih (eds.)). Direktorat Pembinaan Pendidikan Anak Usia Dini.

Wijayanti, A. (2016). Teknik Dasar Pengolahan Data Kuantitatif dengan Program SPSS for Windows Versi 17. Akademi Pariwisata BSI Yogyakarta.

Zaningsih, R. D. (2018). Pengembangan Aplikasi EModul Mobile Pembelajaran Matematika Berbasis Android Studio Pokok Bahasan Matriks. In Skripsi. 